\title{
MOŻLIWOŚĆ PRZEKAZYWANIA DZIALAŃ WYKONAWCZYCH PRZEZ RADĘ GMINY
}

\section{ZAGADNIENIE WSTĘPNE}

Zakres zastosowania art. 39 ust. 4 usg $^{1}$, dotyczący możliwości przekazywania działań organu wykonawczego przez radę gminy, jest zagadnieniem nieustająco budzącym spory interpretacyjne zarówno w doktrynie, jak i w orzecznictwie sądów administracyjnych, a także praktyce orzeczniczej organów nadzoru. Jest to sprawa zaskakująca, jeśli zważyć, że treść tego przepisu od $1990 \mathrm{r}$. w zasadzie nie uległa zmianom². Ostatnio znalazło to wyraz m.in. w orzeczeniu Naczelnego Sądu Administracyjnego z 26 listopada 2013 r. ${ }^{3}$, które niesłusznie spotkało się z krytyką skłaniającą do zabrania głosu ${ }^{4}$.

Przywołane orzeczenie NSA dotyczy dopuszczalnego zakresu stosowania spornego przepisu. Przypomnijmy, że przepis art. 39 ust. 4 usg stanowi podstawę prawną do przekazywania przez radę gminy kompetencji „Do załatwiania indywidualnych spraw z zakresu administracji publicznej” na rzecz organów wykonawczych jednostek pomocniczych gmin oraz organów jednostek i podmiotów, o których mowa w art. 9 ust. 1 usg, a więc na rzecz organów gminnych jednostek organizacyjnych, a także innych podmiotów, w tym organów organizacji pozarządowych, z jakimi gmina zawrze umowę, której przedmiotem jest powierzenie wykonywania zadań gminy.

Zważywszy na przedmiot regulacji art. 39 ust. 4 usg, rozważenia wymaga przyjęty przez prawodawcę zakres jego zastosowania. Nie można pomijać milczeniem sporów o zakres kompetencji organu wykonawczego gminy, które organ uchwałodawczy może przekazać na rzecz innych podmiotów. Kwestia ta wymaga jednoznacznego przesądzenia, tym bardziej że liczne rozbieżności or-

${ }^{1}$ Ustawa z 8 marca 1990 r. o samorządzie gminnym, Dz. U. 2013, poz. 594 ze zm. (dalej jako: usg).

${ }^{2}$ Pomijam zmianę oznaczenia tego przepisu oraz wykreślenie $\mathrm{z}$ jego treści odesłania do art. 5 ust. 1 usg, co nastapiło art. 1 ustawy z 29 września 1995 r. o zmianie ustawy o samorządzie terytorialnym oraz niektórych innych ustaw, Dz. U. 1995, Nr 124, poz. 601.

${ }^{3}$ Wyrok NSA z 26 listopada 2013 r., II OSK 2409/13, Lex, nr 1430374, http://orzeczenia.nsa. gov.pl/doc/F203908E37.

${ }^{4}$ R. Dowgier, Glosa do wyroku NSA z dnia 26 listopada 2013 r. (II OSK 2409/13). Czy gmina może powierzyć czynności zwiazane z wydawaniem decyzji określajacych opłaty za gospodarowanie odpadami komunalnymi innym podmiotom niż wójt, burmistrz (prezydent miasta)?, „Przegląd Podatków Lokalnych i Finansów Samorządowych” 2014, nr 7, s. 34-40. 
ganów nadzoru oraz sądownictwa administracyjnego skutkują tym, że w różnych regionach kraju przyjmowana jest odmienna praktyka w tym zakresie. Taki stan rzeczy nie daje się żadną miara pogodzić z koncepcją państwa prawa jako jedną z podstawowych, konstytucyjnych wartości przyjmowanych w RP.

\section{SEDNO KONTROWERSJI - PRÓBA ZDEFINIOWANIA}

Zagadnieniem, które rodzi najwięcej kontrowersji w kontekście tego umocowania, jest nie tyle możliwość przekazania przez radę gminy, a więc organ uchwałodawczy i kontrolny gminy, innemu podmiotowi kompetencji ustawowo zastrzeżonych na rzecz organu wykonawczego, a więc wójta, burmistrza czy prezydenta (ta kwestia co do zasady nie budzi kontrowersji interpretacyjnych, choć tu właśnie dyskutować można by nad zasadnością takiego rozwiązania legislacyjnego), ile przede wszystkim kwestia przyjętego przez prawodawcę dopuszczalnego zakresu przedmiotowego takiego przekazania.

Artykuł 39 usg kompleksowo reguluje kwestie zwiąane z wydawaniem decyzji administracyjnych, konsekwentnie wskazując $\mathrm{w}$ poszczególnych ustępach - z wyjątkiem budzącego spory ust. 4 - że dotyczy właśnie tej formy działania administracji, i to w sposób niepozostawiajaccy wątpliwości.

Tak więc art. 39 ust. 1 usg przesądza, że „Decyzje w sprawach indywidualny ch [wyróż. - KZ] z zakresu administracji publicznej wydaje wójt" (co do zasady), generalnie umocowując tym samym organ wykonawczy gminy $\mathrm{w}$ sprawach powierzonych gminie do załatwiania w drodze wydawania decyzji w rozumieniu kpa, i to w sposób niemogący budzić wątpliwości. Przewidziano przy tym, że przepisy szczególne (a więc de facto sam prawodawca) przesadzać moga, iż kompetencja ta udzielona zostanie na rzecz innych podmiotów. Przepisem tym zatem w sprawach należących do właściwości gminy ukonstytuowano na rzecz jej organu wykonawczego tzw. domniemanie kompetencji do wydawania decyzji administracyjnych. Sprawą niebudzaca w doktrynie i orzecznictwie kontrowersji jest to, że udzielenie kompetencji do wydawania decyzji administracyjnych jako władczej formy działania administracji musi zostać skonstruowane w sposób jednoznaczny, nigdy w sposób dorozumiany, już choćby z tego powodu, że wydanie decyzji administracyjnej przez organ do tego nieumocowany, jak i wydanie decyzji bez podstawy prawnej, skutkuje jej nieważnością (art. $156 \S 1$ pkt 1 i $2 \mathrm{kpa}$ ). O ile zatem działanie w formie decyzji jako postaci indywidualnego rozstrzygnięcia w sprawach pozostających w zakresie zadań gminy zostanie przez prawodawcę co do formy prawnej przesądzone, bez jednoczesnego, wyraźnego wskazania podmiotu właściwego do jej wydania, podmiotem tym jest organ, o którym mowa w art. 39 ust. 1 usg, tj. wójt (burmistrz, prezydent). Tylko wyraźny przepis rangi ustawowej może przesądzić w tych sprawach o właściwości innego podmiotu. Przepisem tejże rangi można także umocować określony podmiot do dokonania zmian w tym zakresie (udzielić kompetencji), a art. 39 ust. 4 usg stanowi właśnie przejaw skorzystania przez prawodawcę z takiej możliwości. 
W art. 39 ust. 2 usg wskazuje się, iż „wójt może upoważnić swoich zastępców lub innych pracowników urzędu gminy do wydawania decyzji administracyjnych [wyróż. - K.Z.] w swoim imieniu". Przewidziano tym samym wyraźnie nie tylko możliwość udzielenia przez wójta swoistego pełnomocnictwa (umocowania) do wydawania w jego imieniu decyzji administracyjnych, lecz także krąg podmiotów, którym udzielone może zostać takie upoważnienie. Istota owego upoważnienia sprowadza się do tego, że wójt, niezależnie od udzielonego wskazanym podmiotom umocowania, może określoną sprawę załatwić zarówno osobiście, jak i za pośrednictwem innej przez niego upoważnionej osoby, ponosząc przy tym jednak pełną odpowiedzialność za jej działanie. Jest to zatem przejaw zjawiska kwalifikowanego w nauce administracji jako dekoncentracja czy tė̇ dekoncentracja wewnętrzna zadań. Udzielenie pełnomocnictwa nie skutkuje wyzbyciem się przez wójta na rzecz osoby (osób) przezeń upoważnionej kompetencji do wydawania decyzji.

Również uchylony art. 39 ust. 3 usg, podobnie jak ust. 1 i 2 , dotyczył decyzji administracyjnych. Przepis ten regulował sposób reprezentacji organu kompetentnego do wydawania decyzji administracyjnych jeszcze w okresie, kiedy organem wykonawczym gminy pozostawał zarząd ${ }^{5}$ gminy jako organ kolegialny.

Podobnie art. 39 ust. 5 usg dotyczy działań w formie decyzji administracyjnych, wskazując organ właściwy do rozpatrywania odwołań od decyzji wójta (burmistrza, prezydenta), jak również decyzji podmiotów, o których mowa w art. 39 ust. 4 usg, na które to rada gminy przeniosła kompetencje organu wykonawczego.

W art. 39 ust. 4 usg natomiast wskazuje się wyraźnie, iż „do z ała tw i a n ia indywidualnych spraw z zakresu administracji publicznej [...]" (wyróż. - K.Z.) rada gminy może upoważnić wspomniane tym przepisem podmioty. Artykuł 39 ust. 4 usg jest zatem przepisem, który stwarza podstawę prawną dla rady gminy do udzielania innemu niż wójt (burmistrz, prezydent) podmiotowi kompetencji co do zasady przypisanych organowi wykonawczemu. Przesądzono nim o podmiocie umocowanym (rada gminy) do przeniesienia kompetencji wójta jako organu wykonawczego, o zakresie spraw, których przeniesienie to może dotyczyć (wymagajace załatwienia indywidualne sprawy z zakresu administracji publicznej), a także o zakresie podmiotów, na rzecz których to przeniesienie może nastapić (organy wykonawcze jednostek pomocniczych, organy gminnych jednostek organizacyjnych oraz podmiotów, z którymi gmina zawarła umowę celem wykonywania zadań, w tym organizacji pozarządowych).

Istota postanowień art. 39 ust. 4 usg sprowadza się do udzielenia radzie gminy umocowania (kompetencji) do przeniesienia kompetencji innego organu (wójta, burmistrza, prezydenta) będącego organem stricte wykonawczym na wyraźnie wskazane tym przepisem podmioty trzecie. W świetle jednoznacz-

\footnotetext{
5 Przepis art. 39 ust. 3 usg brzmiał: „D e c y zj e [wyróż. - K.Z.] wydawane przez zarząd gminy w sprawach z zakresu administracji publicznej podpisuje wójt lub burmistrz. W decyzji wymienia się imię i nazwisko członków zarządu, którzy brali udział w wydaniu decyzji”. Przepis został uchylony art. 43 pkt 35 lit. c ustawy z 20 czerwca 2002 r. o bezpośrednim wyborze wójta, burmistrza i prezydenta miasta, Dz. U. 2010, Nr 176, poz. 1191 ze zm.
} 
nych postanowień art. 39 ust. 4 usg nie można racjonalnie formułować poglądu, że rada gminy nie ma możliwości przekazania w trybie tego przepisu kompetencji, których sama nie posiada ${ }^{6}$, jak również poglądu, że organy wykonawcze gminy wyposażone są w kompetencje „własne”, którymi nie może dysponować rada gminy. Wszak istotą umocowania wyrażonego w art. 39 ust. 4 usg jest właśnie dopuszczalność dysponowania przez radę gminy kompetencjami innego organu (organu wykonawczego gminy). Pogląd taki jest rezultatem nie dość konsekwentnego rozróżniania takich pojęć, jak zadania i kompetencje, do którego to zagadnienia powrócimy w dalszej części niniejszego opracowania.

\section{PRÓBA ROZWIĄZANIA ZAGADNIEŃ KONTROWERSYJNYCH}

Nie można jednak nie zauważyć, że rada gminy na mocy art. 39 ust. 4 usg dysponować może kompetencjami wójta (burmistrza, prezydenta) jako organu wykonawczego gminy stanowiącej podmiot, któremu ustawodawca powierzył określone zadania publiczne. Przedmiot przekazania bez wątpienia stanowić może kompetencja przypisana organowi wykonawczemu gminy, a więc pozostająca w związku z zakresem zadań przekazanych gminie, i to zarówno jako własne, jak i zlecone na mocy prawa. Sprawą wymagajaca refleksji jest już możliwość przekazania przez radę gminy w trybie art. 39 ust. 4 usg kompetencji powierzonych gminie i jej organom w drodze zawartych porozumień ${ }^{7}$. Porozumienie w zależności od tego, z kim jest zawierane oraz co stanowi jego przedmiot, prowadzić może do wykonywania przez organ wykonawczy gminy zadań w oparciu o odmienne zasady. Nie podejmując tego wątku szczegółowo w niniejszym opracowaniu, wskazać jednak należy chociażby na to, że w przypadku porozumień zawieranych pomiędzy jednostkami samorządu terytorialnego (jst) sprawa przedstawia się inaczej niż w przypadku porozumień zawieranych przez jednostki samorządu terytorialnego, w tym gminę, np. z wojewodą jako organem administracji rządowej ogólnej. W przypadku przekazania przez wojewodę prowadzenia pewnych spraw na rzecz gminy porozumienie zawierane jest z wójtem, jako organem reprezentujacym gminę, i przewidywać musi m.in. zasady sprawowania przez wojewodę kontroli nad prawidłowym wykonywaniem powierzonego zadania czy zadań (art. 20 ust. 3 ustawy o wojewodzie i administracji rządowej w województwie ${ }^{8}$ ). Nadto porozumieniem takim przekazać można prowadzenie spraw wyłącznie w imieniu wojew ody (art. 20 ust. 1 uow). Takich wymogów nie formułują ustawy samorządowe przewidujące, że droga porozumienia następuje wprost przeniesienie zadań i kompetencji na rzecz innej gminy (przejmującej) działającej wówczas poprzez swoje organy reali-

${ }^{6}$ Taki pogląd wyrażony został przez R. Dowgiera, op. cit., s. 39.

${ }^{7}$ Bliżej na temat istoty porozumień zob. np. J. Boć, Porozumienie administracyjne, w: System prawa administracyjnego, t. 5, red. R. Hauser, Z. Niewiadomski, A. Wróbel, C. H. Beck, Warszawa 2013 , s. 260 i n.

${ }^{8}$ Ustawa z 23 stycznia 2009 r. o wojewodzie i administracji rządowej w województwie, Dz. U. 2015, poz. 525 (dalej jako: uow). 
zujące przejęte zadania i kompetencje w imieniu i na rzecz „swojej” gminy, tj. gminy, której są organami (por. art. 74 ust. 2 usg oraz odpowiednio art. 73 ust. $2 \mathrm{w}$ związku z art. 65 ustawy o samorządzie powiatowym ${ }^{9}$ ). Zważywszy na odmienne sformułowanie podstaw prawnych do przekazywania zadań drogą porozumień, zasygnalizować należy, że również z tego powodu treść art. 39 ust. 4 usg rodzi wątpliwości w doktrynie, w konsekwencji prowadząc do rozbieżności judykatury co do tego, co może być przedmiotem uchwał rady podejmowanych na jego podstawie ${ }^{10}$.

Zarówno przyjęta przez prawodawcę systematyka przepisu art. 39 usg, jak i treść poszczególnych jego ustępów wprost wskazujących (z wyłączeniem ust. 4) na decyzję administracyjną jako formę działania administracji, do której się odnosza, skutkuje tym, że część przedstawicieli doktryny, a także częściowo orzecznictwo sądowoadministracyjne oraz orzecznictwo organów nadzoru, odwołując się do argumentum a rubrica, wnioskuje, że skoro w art. 39 ust. 1, 2 oraz 5 (a uprzednio również ust. 3) usg wyraźnie mowa jest o decyzjach administracyjnych, to także w przypadku ust. 4, w którym mowa jest o „załatwianiu spraw indywidualnych z zakresu administracji publicznej ${ }^{11}$, chodzi wyłacznie o sprawy załatwiane w drodze decyzji administracyjnych ${ }^{12}$. Doprowadziło to nawet niektórych autorów, a także składy orzekające sądów administracyjnych do wniosku, że przedmiotem umocowania z art. 39 ust. 4 usg jest wyłacznie samo wydawanie decyzji, a już nawet nie wszelkie inne czynności niezbędne do jej wydania. Wniosek taki jednak jest ewidentnie niezgodny z literalnym brzmieniem art. 39 ust. 4 usg, nie mówiąc już o tym, że pozbawiony jest racjonalności, czyniąc wręcz absurdalnym takie umocowanie.

Jako jeden z argumentów mających jakoby przemawiać za stanowiskiem, iż art. 39 ust. 4 usg dotyczy wyłącznie decyzji administracyjnych, wskazuje się na zawarte w nim wyrażenie ,załatwianie indywidualnych spraw z zakresu administracji publicznej”. Według zwolenników tego poglądu jest to pojęcie o charakterze procesowym, którym prawodawca posłużył się już dużo wcześ-

${ }^{9}$ Ustawa z 5 czerwca 1998 r. o samorządzie powiatowym, Dz. U. 2013, poz. 595 ze zm. (dalej jako: usp).

${ }_{10}$ Zob. np. wyrok WSA w Gorzowie Wielkopolskim z 11 kwietnia 2013 r., II SA/GO/147/13, http://orzeczenia.nsa.gov.pl/doc/EF9B12A8B6; wyrok WSA w Gliwicach z 24 sierpnia 2010 r., IV SA/GI/845/09, http://orzeczenia.nsa.gov.pl/doc/234CF80D21; wyrok WSA w Opolu z 24 listopada 2009 r., II/SA/Op/318/09, http://orzeczenia.nsa.gov.pl/doc/548F6A2CFF; wyrok WSA w Opolu z 7 lipca 2009 r., II/SA/Op/134/09, http://orzeczenia.nsa.gov.pl/doc/AF27E7EE9A.

${ }_{11}$ Por. np. A. Szewc, Komentarz do art. 39 ust. 4 usg, Lex/el.2012. A także R. Dowgier, op. cit., s. 37. Autor, uzasadniając odmienną od przyjętej przez sądy interpretację art. 39 ust. 4 usg, bez odwoływania się do jakiejkolwiek argumentacji, przyjął za oczywistość, że określenie „,indywidualna sprawa z zakresu administracji publicznej” jest synonimem użytego w art. 1 pkt 1 kpa określenia „sprawa indywidualna rozstrzygana w drodze decyzji administracyjnej”.

${ }^{12}$ Wyrok WSA w Gliwicach z 9 stycznia 2014 r., IV SA/GL/876/13, Lex, nr 1532137, teza $2 \mathrm{http} / / /$ orzeczenia.nsa.gov.pl/doc/4881fe47fa; wyrok WSA we Wrocławiu z 28 czerwca $2013 \mathrm{r}$., III/SA/Wr300/13, „Nowe Zeszyty Samorządowe” 2013, nr 5, poz. 66, http://orzeczenia.nsa.gov. pl/doc/F25245E906; wyrok NSA z 23 października 2008 r., I OSK/701/08, http://orzeczenia.nsa. gov.pl/doc/E6D272B614, którym uchylono wyrok WSA w Rzeszowie z 25 października 2007 r., II SA/Rz/559/07. Zob. także orzecznictwo NSA i SN, które NSA podzielił w powołanym powyżej wyroku. 
niej (przed ustanowieniem usg) w ustawie - Kodeks postępowania administracyjnego (art. 1 ust. $1 \mathrm{kpa})^{13}$, wyraźnie wiążąc załatwianie spraw indywidualnych z wydawaniem decyzji ${ }^{14}$.

Skutkować ma to w opinii niektórych przedstawicieli doktryny koniecznością utożsamiania pojęcia „decyzja administracyjna” z pojęciem „załatwianie sprawy o charakterze indywidualnym”. Wniosek o tożsamości zakresowej pojęć, o których mowa w art. 39 ust. 1, 2, 5 oraz art. 39 ust. 4 usg, jest oczywista konsekwencją takiego poglądu ${ }^{15}$. Argumentacja ta - należy to stwierdzić z cała moca - jest nietrafna.

Wskazany pogląd prowadzi do wniosku, że skoro sprawa indywidualna, o której mowa w Kodeksie postępowania administracyjnego, jest sprawą rozstrzyganą aktem indywidualnym (decyzja), to ilekroć w przepisach mowa jest o sprawie indywidualnej z zakresu administracji publicznej, jej załatwienie następuje droga wydania rozstrzygnięcia (a więc załatwienie) w formie decyzji. Tymczasem pojęcie „sprawa indywidualna” jest pojęciem o charakterze doktrynalnym, wykształconym w nauce prawa administracyjnego w ramach szeroko rozumianej koncepcji form prawnych działania administracji ${ }^{16}$, i to w okresie zdecydowanie poprzedzajacym przyjęcie regulacji o charakterze procesowym, dotyczących trybu wydawania najbardziej dolegliwych dla jednostki, typowych dla administracji działań władczych. Tak więc jedna tylko $\mathrm{z}$ możliwych form działania administracji w sprawach indywidualnych jest decyzja stanowiąca rozstrzygnięcie indywidualnej sprawy z zakresu administracji publicznej, a więc kwalifikowana postać działań władczych, której tryb wydawania jako przejawu szczególnego, władczego kształtowania treści stosunków materialnoprawych uregulowano w odrębnej procedurze administracyjnej (w naszym przypadku kpa, a uprzednio rozporządzeniu Prezydenta Rzeczypospolitej z 22 marca 1928 r. o postępowaniu administracyjnem ${ }^{17}$ ).

Już na wstępie w przedmiotowym zakresie wskazać należy, że żadną miara pojęcia „sprawa indywidualna” nie można utożsamiać ze sposobem jej załatwiania, a więc jej załatwianiem, tak jak, ,załatwiania” nie można utożsamiać z „rozstrzyganiem”. Samo pojęcie „indywidualna sprawa z zakresu administracji publicznej” ma zdecydowanie szersze znaczenie niż „indywidualna sprawa z zakresu administracji publicznej rozstrzygana decyzją administracyjną. Nie każda sprawa indywidualna wymaga bowiem do jej załatwienia rozstrzygnięcia zagadnienia prawnego rozumianego jako przesądzenie o konsekwencjach prawnych określonego, ustalonego przez organ stanu faktycznego $^{18}$, a więc wydania decyzji administracyjnej. Tymczasem jednym ze źró-

${ }^{13}$ Ustawa z 14 czerwca 1960 r. - Kodeks postępowania administracyjnego, t.jedn.: Dz.U. 2013, poz. 267 ze zm (dalej jako: kpa).

14 Por. np. A. Szewc, op. cit., oraz R. Dowgier, op. cit., s. 37.

15 Zob. np. R. Dowgier, op. cit., s. 34.

${ }^{16} \mathrm{Na}$ temat kształtowania się poglądów co do istoty poszczególnych form prawnych działania administracji zob. np. K. Ziemski, Indywidualny akt administracyjny, WN UAM, Poznań 2005, zwł. s. 96-137, oraz idem, Próba rekonstrukcji typologii form prawnych działania administracji przyjmowanej $w$ doktrynie, w: System..., t. 5, s. 59-76.

${ }^{17}$ Rozporządzenie Prezydenta Rzeczypospolitej z 22 marca 1928 r. o postępowaniu administracyjnem, Dz. U. 1928, Nr 36, poz. 341.

${ }_{18}$ Por. K. Ziemski, Indywidualny akt administracyjny..., s. 458-516, w szczególności s. $467 \mathrm{in}$. 
deł niewłaściwego rozumienia art. 39 ust. 4 usg, jak się zdaje, jest wskazane błędne utożsamianie pojęcia indywidualnej sprawy z określonym sposobem jej załatwienia (i to ze sposobem częstokroć określanym wprost jako rozstrzyganie), a więc utożsamianie przedmiotu wymagającego aktywności administracji (sprawy) z określoną czynnością (bądź ich zespołem) podmiotu administracji publicznej, stanowiąca przewidziany w kpa sposób jej załatwienia.

Przypomnieć wypada w tym miejscu, że indywidualną sprawą z zakresu administracji publicznej jest każda sytuacja faktyczna skonkretyzowana zarówno od strony podmiotowej (indywidualnie oznaczony adresat), jak i przedmiotowej (stwierdzony przez organ zespół okoliczności faktycznych), stanowiąca przedmiot zainteresowania administracji publicznej (przedmiot wymagajacy aktywności administracji). Każde natomiast prawem przewidziane działanie administracji publicznej, załatwiające taką sprawę (czy mające ją załatwić), a także zmierzające do jej załatwienia, stanowi przejaw aktywności administracji (czynność faktyczną bądź konwencjonalną albo ich zespół), a więc ,jej załatwienie". Może to być działanie (czynność) zarówno o charakterze prawnym, a więc również takie, jak wydanie decyzji administracyjnej stanowiącej przesądzenie (rozstrzygnięcie) o konsekwencjach prawnych danego stanu faktycznego $^{19}$ (takiego pojmowania decyzji nie należy utożsamiać z pojęciem tzw. formalnym decyzji, a więc decyzji jako substratu materialnego będącego nośnikiem treści rozstrzygnięcia odpowiadającego wymogom określonym w art. $107 \mathrm{kpa})^{20}$, jak i działanie o charakterze faktycznym, a więc czynność (bądź zespoły czynności) o charakterze materialnotechnicznym, taka jak np. wypłata zasiłku określonej osobie, wypłata dodatku energetycznego, udzielenie pomocy medycznej określonej osobie, udzielenie informacji, wezwanie, dokonanie wpisu do ewidencji, przyjęcie deklaracji, wydanie zaświadczenia, dokonanie czynności kontrolnych i wiele innych działań. Pojęcie „indywidualna sprawa z zakresu administracji publicznej” nie może być zatem żadna miarą utożsamiane z jakąkolwiek formą działania administracji publicznej, ponieważ odnosi się ono do wyróżnianego w oparciu o powyżej wskazane kryterium przedmiotu aktywności administracji, a nie sposobu jego załatwienia.

Pojęcie indywidualnej sprawy z zakresu administracji publicznej jest zatem przede wszystkim, a już przynajmniej również, pojęciem materialnoprawnym, a nie wyłącznie procesowym i choć przeniesione zostało do ustawy proceduralnej (kpa), to jednak nie wyłącznie w celach procesowych. Uczyniono to celem sprecyzowania cech przedmiotu działań administracji, majacych przesądzać o jego (przedmiotu) konsekwencjach, i to przede wszystkim konsekwencjach materialnoprawnych. W kpa charakter sprawy (konkretny i indywidualny) przesądza tym samym jednoznacznie także o cechach decyzji jako postaci rozstrzygnięcia o konsekwencjach materialnoprawnych. Z uwagi na przedmiot rozstrzygania (a więc sprawę indywidualną zarówno, co do adresata jak i okoliczności), rozstrzygnięcie do którego ono się odnosi, siłą rzeczy także musi wykazywać cechy charakterystyczne dla rozstrzyganej sprawy,

19 J. Borkowski, Zakres obowiazywania, w: B. Adamiak, J. Borkowski, Kodeks postepowania administracyjnego. Komentarz, wyd. 13, C. H. Beck, Warszawa 2014, s. 11 i n., a zwłaszcza s. 12.

${ }^{20}$ Jak również z pojęciem decyzji w znaczeniu procesowym por. np. ibidem, s. 14 . 
a więc indywidualność i konkretność. Samo określenie „decyzja administracyjna” zatem, choć wyraźnie sformułowane w ustawie z istoty swej procesowej, nie ma charakteru wyłącznie procesowego, lecz również, a może nawet przede wszystkim - materialnoprawny. Decyzją bowiem kończy się co prawda postępowanie administracyjne ${ }^{21}$, jednak co do zasady wiąże się to $\mathrm{z}$ osiagnięciem celu, dla którego je prowadzono, a więc określeniem treści stosunku administracyjnoprawnego, i to materialnego, drogą rozstrzygnięcia (przesądzenia) o treści praw i obowiązków indywidualnego adresata, co wskazuje się wręcz jako istotę pojęcia „decyzja administracyjna” ${ }^{22}$.

Za kolejne nieporozumienie mogace prowadzić do błędnego wniosku o tożsamości zakresowej pojęć, o których mowa w całym art. 39 usg, uznać należy utożsamianie pojęcia „załatwianie” z pojęciem „rozstrzyganie sprawy”. Podkreślenia wymaga, że załatwienie indywidualnej sprawy, o której mowa w Kodeksie postępowania administracyjnego, wymaga właśnie rozstrzygnięcia przez organ o konsekwencjach prawnych dla określonego indywidualnie adresata $\mathrm{w}$ skonkretyzowanym stanie faktycznym i to tryb wydawania takich rozstrzygnięć uregulowany jest tą ustawa. Stwierdzić należy zatem, że w Kodeksie mowa jest tylko o jednym z wielu możliwych sposobów, a więc form załatwiania spraw indywidualnych ${ }^{23}$. Już z samego literalnego brzmienia art. 1 ust. 1 kpa w powiązaniu z art. 104 kpa wywnioskować można, że załatwienie sprawy na gruncie Kodeksu co do zasady równoznaczne jest z rozstrzygnięciem o jej konsekwencjach prawnych. Decyzja bowiem wydawana jest w sprawach wymagających rozstrzygnięcia, stanowiąc przy tym owo rozstrzygnięcie, załatwiające przedmiot postępowania, a więc sprawę o cechach wskazanych $\mathrm{w}$ art. 1 ust. 1 kpa. Wyłącznie zatem w sprawach, o których mowa w art. 1 ust. $1 \mathrm{kpa}$, a więc wymagajacych rozstrzygnięcia o konsekwencjach prawnych dla zindywidualizowanego stanu faktycznego, ich załatwienie obligatoryjnie następuje przez wydanie decyzji administracyjnej. Na gruncie Kodeksu zatem załatwienie sprawy indywidualnej równoznaczne jest z jej rozstrzygnięciem. Sprawy niewymagajace rozstrzygnięcia w formie decyzji załatwiane moga, a nawet muszą być w inny, prawem przewidziany sposób, a więc w innych niż decyzja administracyjna formach prawnych działania.

Nie bez merytorycznego uzasadnienia zatem w art. 39 usg raz mówi się o działaniach w formie decyzji administracyjnej, czy też decyzji w indywidualnej sprawie (tak art. 39 ust. 1, 2, 5 usg), a raz o wymagajacych załatwienia indywidualnych sprawach z zakresu administracji publicznej (art. 39 ust. 4 usg).

Gwoli przypomnienia, a przy tym wzmocnienia argumentacji, wskazać można w tym miejscu jedna z podstawowych reguł legislacyjnych (zasad) przyjmowanych w naszym systemie prawnym, która wyrażona została w $§ 10$ Zasad techniki prawodawczej $)^{24}$. W myśl tejże zasady do oznaczenia jednakowych po-

${ }^{21}$ J. Borkowski, Komentarz..., s. 426.

${ }_{22}$ Por. np. ibidem, s. 427, a także K. Ziemski, Typologie indywidualnych aktów administracyjnych, w: System..., t. 5, s. 178-197.

${ }^{23} \mathrm{Z}$ uwagi na przedmiot opracowania pomijam pozostałe działania administracji objęte zakresem zastosowania kpa.

${ }^{24}$ Rozporządzenie Prezesa Rady Ministrów z 20 czerwca 2002 r. w sprawie „Zasad techniki prawodawczej”, Dz. U. 2002, Nr 100, poz. 908 (dalej jako: ztp). 
jęć używać należy jednakowych określeń, a różnych pojęć nie należy oznaczać tymi samymi określeniami. Nadto z $§ 9$ ztp wynika reguła, iż w ustawie należy posługiwać się określeniami, które zostały użyte w ustawie podstawowej dla danej dziedziny spraw, w szczególności w ustawie określanej jako „kodeks” lub „prawo”. Treści powyżej wymienionych reguł nie można pomijać, interpretujac art. 39 usg. Konsekwentne posługiwanie się w art. 39 w ust. 1, 2 i 5 (a dawniej także art. 39 ust. 3 usg) terminologia przyjętą w kpa, jednoznacznie odwołująca się do pojęcia „decyzja administracyjna”, a więc rozstrzygnięcia indywidualnej sprawy, wskazuje jednoznacznie na odwoływanie się do formy prawnej, której wydawanie reguluje kpa. Jednocześnie posłużenie się w art. 39 ust. 4 usg pojęciem „załatwianie indywidualnych spraw” bez wskazywania formy, w jakiej ma to nastapić, nie może być interpretowane jako przypadkowe, będące wynikiem niezręczności czy wręcz wadliwości legislacyjnej, lecz jako rezultat celowego odwoływania się przez prawodawce do wszelkich form realizacji zadań publicznych (działań i czynności) z wyraźnym zamiarem nieograniczania zakresu przedmiotowego tej regulacji do tej tylko formy, o której mowa w pozostałych ustępach art. 39 usg (tj. decyzji administracyjnej).

W rezultacie stwierdzić należy, że przepis art. 39 ust. 4 usg stanowi dopełnienie treści pozostałych ustępów art. 39 usg w tym sensie, że dotycząc swoim zakresem wszelkich form działania administracji, w jakich moga być załatwiane sprawy indywidualne, odnosi się także, ale nie wyłącznie, do decyzji administracyjnych.

Przedmiot regulacji art. 39 ust. 4 usg jest zatem diametralnie odmienny od przedmiotu regulacji pozostałych ustępów art. 39 usg $^{25}$. Odmienność ta przejawia się $\mathrm{w}$ dwóch istotnych aspektach. Po pierwsze w art. 39 ust. 4 usg przedmiotem kompetencji rady gminy objęte jest wszelkie „załatwianie indywidualnych spraw z zakresu administracji publicznej”, mieszczące się w zakresie kompetencji wójta (burmistrza, prezydenta), a więc we wszystkich prawem przewidzianych formach, a nie tylko załatwianych w drodze decyzji administracyjnej. Po drugie, konsekwencją upoważnienia przez radę gminy podmiotów, o których mowa w art. 39 ust. 4 usg, do załatwiania indywidualnych spraw jest pozbawienie organu wykonawczego gminy (wójta, burmistrza, prezydenta) kompetencji objętych udzielonym upoważnieniem (ich przeniesienie na inny podmiot). W art. 39 ust. 4 usg wskazuje się, nie jak w przypadku art. 39 ust. 2 usg, na możliwość umocowania określonych osób do działania $\mathrm{w}$ imieniu organu wykonawczego w zakresie rozstrzygania spraw o charakterze indywidualnym drogą wydawania decyzji, lecz możliwość przeniesienia wskazanych uchwała kompetencji organu wykonawczego gminy do załatwiania spraw indywidualnych na inny podmiot, a więc dokonanie decentralizacji kompetencji rozumianej jako przeniesienie w prawem przewidziany sposób danych kompetencji na inny podmiot.

Sprawa, która rodzić może kontrowersje, jest zasadność udzielenia radzie gminy, a więc organowi uchwałodawczo kontrolnemu, co do zasady niewyposażonemu w kompetencje do załatwiania spraw indywidualnych, umocowania

${ }_{25}$ Tak również część orzecznictwa, zob. np. powoływany już wyrok NSA z 26 listopada 2013 r., II OSK 2409/13, Lex, nr 1430374. 
do dokonania przesunięcia kompetencji należących do organu wykonawczego na podmiot trzeci, i to ze skutkiem pozbawienia go określonych kompetencji przy jednoczesnym wyposażeniu w nie innego podmiotu. Oznacza to, że rada gminy praktycznie bez udziału organu wykonawczego, a niekiedy nawet wbrew jego woli, przekazać może jego kompetencje na rzecz podmiotu trzeciego. Organ wykonawczy pozbawiony zostaje w tym przypadku możliwości nadzorczych nad podmiotem, na który rada przeniosła jego kompetencje, a nawet pozbawiony może być wykonywania działań kontrolnych. W wyniku uchwały rady gminy podjętej w trybie art. 39 ust. 4 usg organ wykonawczy gminy pozbawiony zostaje określonych, ustawowo jemu przypisanych kompetencji, jak również możliwości wykonywania zadań w formie (formach) przekazanej innemu podmiotowi. W rezultacie podmiot wskazany uchwała rady podjęta w trybie art. 39 ust. 4 usg nabywa określone kompetencje, a więc ma możność, a niekiedy także obowiązek wykonywania zadań gminy w formach, które w drodze uchwały rady gminy zostały mu przekazane.

Szerszej refleksji wymaga w tym kontekście rozważenie zakresu działań możliwych do podejmowania przez podmiot umocowany w trybie art. 39 ust. 4 usg nie tylko w ramach, ale także w związku z udzielonym upoważnieniem. Wymaga to rozważenia dopuszczalnych granic przekazania określonych zadań i kompetencji przez radę, a więc nie tylko tego do działań, w jakich formach udzielić można upoważnienia, ale także w jakim przedmiotowo określonym zakresie zadań umocować można do podejmowania określonych działań. W przypadku analizowanym, a więc uprawnień przekazanych przez radę gminy, wstępnego sprecyzowania wymaga, czy dotyczyć to może wyłącznie zakresu zadań ustawowo przekazanych gminie, zarówno jako własne, jak i zlecone, czy też także zadań powierzonych gminie na podstawie np. porozumień, i to bez względu na to, z kim są zawierane ( $\mathrm{z}$ administracją rządową czy też administracją samorządowa), czy też z uwagi na sygnalizowany już zróżnicowanie podstaw prawnych do zawierania porozumień oraz potencjalnie mogące płynąć stąd odmienności, zakres ten będzie zróżnicowany.

Bardziej szczegółowego wyjaśnienia wymaga także relacja pomiędzy zakresem przekazanych uchwałą rady podjętą w trybie art. 39 ust. 4 usg zadań oraz kompetencji do podejmowania działań wyłącznie w formach wyraźnie uchwała wskazanych, a ewentualnym dopuszczalnym zakresem podejmowania działań także w innych, choć wyraźnie nieprzekazanych formach, to jednak stanowiących działania instrumentalne w stosunku do działań przekazanych bądź funkcjonalnie z nimi powiązane. Rodzi to wątpliwości o różnym charakterze z tego powodu, że część tych działań nie stanowi form załatwiania indywidualnych spraw (a tylko takie mogą być przekazane w trybie art. 39 ust. 4 usg), a część co prawda mogłaby być zakwalifikowana jako zmierzające do załatwienia, czy wręcz załatwiające określone sprawy indywidualne, jednak pozostaja one funkcjonalnie powiązanymi z działaniami podejmowanymi $\mathrm{w}$ formach, co do których wyraźnie udzielono upoważnienia, czy też wręcz instrumentalnymi w stosunku do nich. Celem zilustrowania zagadnienia wskazać można na umocowanie do wydawania decyzji administracyjnych. Decyzja z istoty swej kończy postępowanie administracyjne w sprawie, a więc wymaga uprzednie- 
go wszczęcia postępowania, a dalej jego przeprowadzenia w tym wydawania $\mathrm{w}$ toku postępowania postanowień w kwestiach wpadkowych (np. dopuszczania do udziału na prawach strony, zawieszania postępowania, przywracania terminów i wiele innych) oraz dokonywania czynności materialno-technicznych (takich jak czynności dowodowe, przeprowadzania rozprawy, wzywanie do osobistego, prowadzenia akt, ich udostępnianie, sporządzanie odpisów, stawiennictwa i całego szeregu innych działań). Wątpliwości dotyczą tego, czy wyraźne umocowanie do działania w formie decyzji (jako jednej z postaci załatwiania spraw indywidualnych) wymaga równie wyraźnego umocowania także do podejmowania działań w stosunku do nich instrumentalnych oraz funkcjonalnie z nimi powiązanych (por. wskazane powyżej przykłady działań niezbędnych do przygotowania i wydania decyzji).

W rozważaniach co do zakresu możliwych do przekazania kompetencji uwzględnić należy także działania, które moga, a niekiedy wręcz musza być podejmowane przez podmiot, któremu powierzono określone kompetencje. Rozróżnienia wymaga w szczególności to, czy dopuszczalne i celowe jest przekazywanie kompetencji do podejmowania działań, do których ustawowo zobowiąany jest określony podmiot z tej racji, że realizuje przekazane mu kompetencje podmiotu publicznego, sprowadzające się do załatwiania spraw o charakterze publicznym. Przekazanie podmiotowi, o którym mowa w art. 39 ust. 4 usg, określonych kompetencji organu wykonawczego gminy skutkuje tym, że staje się on podmiotem prawa publicznego o cechach organu administracji publicznej (co najmniej organem w tzw. ujęciu funkcjonalnym) z wszelkimi tego konsekwencjami. Podmiot taki zobowiązany jest wskutek tego do przestrzegania całego szeregu przepisów prawa publicznego, w tym realizowania obowiązków związanych z nabyciem określonego statusu. Celem przykładu tylko wskazać można, że podmiot taki jako dysponujący określonymi informacjami (danymi) zobowiązany jest np. do wydawania zaświadczeń na zasadach i w trybie określonym w Kodeksie postępowania administracyjnego ${ }^{26}$, do załatwiania skarg i wniosków w trybie Działu VIII kpa ${ }^{27}$ czy do udzielania informacji publicznych w trybie i na zasadach określonych ustawą o dostępie do informacji publicznej ${ }^{28}$. Każde z tych działań dotyczy spraw kwalifikowanych jako indywidualne, a podjęcie każdego ze wskazanych działań kwalifikowane jest jako załatwianie indywidualnych spraw, i to w różnych formach prawnych, w tym także drogą wydawania rozstrzygnięć indywidualnych.

Celem uzyskania jednoznacznej odpowiedzi na tak postawione pytania, zasygnalizowania co najmniej wymaga kwestia relacji kluczowych z punktu widzenia wymaganych analiz pojęć, takich jak „zadanie” oraz „kompetencja”29.

${ }^{26}$ Co zakwestionował w rozstrzygnięciu nadzorczym z 30 kwietnia 2013 r. Wojewoda Dolnośląski, NR NK-N.4131.7.13.2013 GD1.

${ }_{27} \mathrm{Na}$ temat charakteru prawnego „załatwiania” skarg i wniosków zob. np. K. Ziemski, Glosa do postanowienia WSA w Biatymstoku z dnia 21 maja 2008 r., II SA/Bk 22/08, „Orzecznictwo Sądów Polskich” 2009, nr 10, poz. 103.

${ }_{28}$ Ustawa z 6 września 2001 r. o dostępie do informacji publicznej, Dz. U. 2014, poz. 782 ze zm.

${ }^{29}$ Bliżej na temat pojmowania kompetencji zwłaszcza w prawie administracyjnym zob. M. Matczak, Kompetencja w prawie administracyjnym, w: System prawa administracyjnego, t. 1, red. R. Hauser, Z. Niewiadomski, A. Wróbel, C. H. Beck, Warszawa 2010, s. 359 i n. oraz s. 384 i n., a także literatura tam przytaczana. 
Zazwyczaj określenie „zadania” rozumiane jest jako zakres praw przekazanych danemu podmiotowi do załatwienia bądź zastrzeżonych dla niego, czy też szerzej - jako zakres spraw, które stanowić mają przedmiot zainteresowań danego podmiotu. Niekiedy, zwłaszcza w opracowaniach starszych, stosuje się określenie „normy zadaniowe” jako synonim przepisów wyznaczających zakres spraw powierzonych danemu podmiotowi. W takim też rozumieniu posługuje się określeniem „zadania” polski prawodawca np. w samorządowych ustawach ustrojowych, a więc w usg, usp oraz ustawie o samorządzie wojewódzkim ${ }^{30}$. W ustawie o samorządzie gminnym w rozdziale 2 zatytułowanym „Zakres działania i zadania gminy”, wskazuje się, co stanowić ma przedmiot zainteresowań gminy jako jednostki samorządu terytorialnego. W art. 6 ust. 1 usg wskazano ogólnie, że „Do zakresu działania gminy należą wszystkie sprawy publiczne o znaczeniu lokalnym, niezastrzeżone na rzecz innych podmiotów”. Bardziej szczegółowo zakres zadań powierzonych gminie określaja art. 7 oraz 8 usg, zarówno co do zakresu zadań określonych jako własne, jak i zlecone. Pozostałe przepisy w tym rozdziale regulują już sprawy odmienne, a więc kwestię form organizacyjnoprawnych, w jakich gmina może realizować powierzone jej zadania. Podobnie w ustawie o samorządzie powiatowym w rozdziale 2 ,Zakres działań i zadania powiatu” wskazano na zadania powiatu. Zatem art. 4 usp określa, jakie zadania publiczne realizuje powiat, wyliczając enumeratywnie powierzone powiatowi zadania publiczne o charakterze ponadgminnym. W ustawie o samorządzie województwa wskazuje się z kolei w rozdziale 2 na „Zakres działalności” samorządu województwa, bliżej określony w art. 11 usw.

Choć materia uregulowana samorządowymi ustawami ustrojowymi nie jest do końca uporządkowana pod względem terminologicznym, to jednak pozwala na sformułowanie wniosków co do zakresu przypisywanego tym pojęciom przez prawodawcę. Wskazać można zatem, że pojęcia „zakres działania” oraz „zadania” stosowane są o różnym stopniu szczegółowości, w przepisach określających zakres spraw mających stanowić przedmiot zainteresowania określonych podmiotów publicznoprawnych. W analizowanym w niniejszym opracowaniu przypadku chodzi o przepisy określające zadania jednostek samorządu terytorialnego, a więc odpowiednio gmin, powiatów oraz województw. Pojęcie „kompetencja” natomiast ani nie zostało przez prawodawcę zdefiniowane, ani nie dał on dostatecznych podstaw do ustalenia jego treści drogą wnioskowań, a więc konieczne staje się odwołanie w tym zakresie do ustaleń teorii prawa oraz doktryny. W piśmiennictwie pojęcie to rozumiane bywa w sposób zróżnicowany ${ }^{31}$. Niekiedy wskazuje się na „zakres kompetencji” jakiegoś podmiotu rozumiany jako zakres powierzonych mu spraw. Pokrywa się to z pojmowaniem „zadań” w powyżej wskazany sposób. Niekiedy zakresem tego pojęcia obejmuje się zarówno zakres powierzonych spraw, jak i możliwe sposoby, a więc formy prawne ich załatwiania. W znaczeniu węższym, nawiązującym do dorobku teorii prawa, przyjmuje się, że kompetencja oznacza dopuszczalne formy realizacji zadań, a więc wskazanie, w drodze jakich i jak dokonywanych

${ }^{30}$ Ustawa z 5 czerwca 1998 r. o samorządzie województwa, t. jedn.: Dz. U. 2013, poz. 596 ze zm.

${ }^{31}$ M. Matczak, op. cit., s. 375 i n. 
czynności (faktycznych bądź konwencjonalnych) realizowane mają bądź moga być zadania powierzone danemu podmiotowi, zwłaszcza czynności (zachowania) kompetentnego skutkujące powstaniem obowiązu dla ich adresata. Działania takie (akty czy też czynności prawne bądź faktyczne) podejmowane moga być tylko przez ustawowo wskazane podmioty (takie jak np. organy administracji państwowej bądź samorządowej, bądź inne), którym udzielono kompetencji, a więc podmioty kompetentne, a niekiedy także zobowiązane do podejmowania działań w określonych formach ${ }^{32}$.

Z pewną dozą uproszczenia stwierdzić można, zatem że w przypadku samorządu terytorialnego zadania spoczywają na określonych samorządowych podmiotach publicznoprawnych, jakimi sa jednostki samorządu terytorialnego. Realizowane sa one głównie przez ich organy w formach ustawowo wskazanych, a więc $\mathrm{w}$ odpowiednich formach prawnych działania. Podmiotami, którym przypisano kompetencje, są zatem zawsze określone organy bądź inne podmioty, które działając $\mathrm{w}$ prawem wskazanych formach, realizuja zadania publiczne w imieniu i na rzecz jst jako określonych podmiotów prawa publicznego ${ }^{33}$. W przypadku jst zadania co do zasady realizowane są w pierwszej kolejności przez ich organy (w przypadku gmin przez radę gminy i wójta burmistrza czy prezydenta), działające przy pomocy odpowiednich urzędów bądź też z wykorzystaniem prawem przewidzianych form organizacyjnoprawnych, takich jak jednostki i zakłady budżetowe, a także spółki prawa handlowego, komunalne osoby prawne czy z odwołaniem się do takich form współdziałania, jak zawieranie porozumień czy też tworzenie związków komunalnych, a także przez podmioty, na które w sposób ustawowo wskazany można przenosić określone kompetencje (np. w trybie analizowanego art. 39 ust. 4 usg).

Pojęć kompetencji i zadań nie można analizować z pominięciem znaczenia normy kompetencyjnej jako pojęć ściśle ze sobą powiązanych. Opowiadając się za koncepcją normy kompetencyjnej w ujęciu tzw. poznańskiej szkoły teorii prawa (obecnie określanej jako poznańsko-szczecińska), a zwłaszcza w ujęciu jej twórcy Profesora Zygmunta Ziembińskiego ${ }^{34}$, przyjąć konsekwentnie należy, że podmiot kompetentny do wydawania decyzji administracyjnych nie jest umocowany do ich wydawania w nieograniczonym zakresie, lecz wyłącznie w zakresie zadań, które on realizuje, w celu ich realizacji właśnie. Nie można zatem udzielać kompetencji do dokonywania określonych czynności (działań) w oderwaniu od zadań, których realizacji mają one służyć. Sprawą niejako

${ }^{32}$ Z. Ziembiński, Kompetencja i norma kompetencyjna, „Ruch Prawniczy, Ekonomiczny i Socjologiczny" 31, 1969, z. 4, s. 23-41 oraz idem, Problemy podstawowe prawoznawstwa, PWN, Warszawa 1980, s. 160-172.

${ }^{33}$ Pomijam tutaj kompetencje udzielane innym podmiotom, $\mathrm{w}$ tym podmiotom prawa prywatnego, takim jak jednostka (osoba fizyczna), spółka prawa handlowego czy inny podmiot wyposażony w osobowość prywatnoprawną.

${ }^{34}$ Zgodzić należy się z poglądem, że określenie zadań oraz sposobu, w jaki mają być realizowane (sposobu dokonywania czynności konwencjonalnych), a także podmiotu kompetentnego, a więc umocowanego do ich podejmowania, stanowi niezbędne elementy składowe normy kompetencyjnej. Oznacza to, że podjęcie kompetencji jest nierozerwalnie powiązane z zadaniami m.in. w tym sensie, że korzystanie z udzielonego umocowania (udzielonej kompetencji) możliwe jest wyłącznie w zakresie mieszczącym się w ramach powierzonych zadań. 
pierwotną zatem jest zdefiniowanie zakresu zadań powierzonych podmiotowi w imieniu i na rzecz którego działa określony organ publicznoprawny, nawet jeśli jest to wyłącznie organ w tzw. ujęciu funkcjonalnym.

W świetle powyższych spostrzeżeń zasadne jest twierdzenie, że rada gminy może w trybie art. 39 ust. 4 usg przekazać kompetencje do załatwiania spraw indywidualnych w zakresie realizacji zadań, które ustawodawca powierzył gminie. Sprawą mogącą budzić wątpliwości jest możliwość przekazania kompetencji związanych z zakresem zadań powierzonych gminie na mocy porozumień, do czego powrócimy poniżej.

Sprawą budząca kontrowersje zarówno w świetle doktryny, jak i orzecznictwa jest dopuszczalność przekazywania przez radę gminy w trybie art. 39 ust. 4 usg na rzecz określonych tam podmiotów do wykonywania kompetencji wójta (burmistrza, prezydenta) w celu realizacji zadań uregulowanych ustawą Ordynacja podatkowa ${ }^{35}$. Zważywszy jednak na to, że wójt (burmistrz, prezydent), podejmując działania $\mathrm{w}$ trybie Ordynacji podatkowej, dokonuje tego w zakresie zadań powierzonych gminie, przyjąc należy, że ani sam fakt uregulowania tych spraw odrębną ustawa, ani charakterystyka tych spraw, ani też szczególny tryb ich załatwiania (uzasadniany charakterystyką tych spraw) nie może stanowić dostatecznej podstawy do twierdzenia o niedopuszczalności takiego upoważnienia. To, że przedmiotem działania organu wykonawczego sa publicznoprawne świadczenia pieniężne, nie zmienia istoty zagadnienia. Nadal sa to kompetencje organu wykonawczego gminy pozostające w bezpośrednim związku z zakresem zadań realizowanych przez gminę. Ewentualne ograniczenia zakresu zastosowania art. 39 ust. 4 usg musiałyby zatem zostać wprowadzone ustawą Ordynacja podatkowa wprost jako wyraźne odstępstwo od ogólnej regulacji (lex generalis) wyrażonej w ustawie ustrojowej dotyczącej funkcjonowania gminy jako jednostki samorządu terytorialnego, w tym realizowania zadań gminy przez jej organy.

W konkluzji zatem stwierdzić należy, że przekazywanie przez radę w trybie określonym art. 39 ust. 4 usg kompetencji wójta (burmistrza, prezydenta) realizującego kompetencje, o których mowa w ustawie Ordynacja podatkowa, wobec braku wyraźnych ograniczeń w tym zakresie, jest dopuszczalne.

Powróćmy do możliwości przekazania w trybie art. 39 ust. 4 usg kompetencji organu wykonawczego gminy pozostających $\mathrm{w}$ związku $\mathrm{z}$ zadaniami nabytymi przez gminę droga zawartego porozumienia. Przyjęcie za trafne stanowiska, że w drodze porozumienia komunalnego następuje przekazanie zadań na rzecz innej gminy, które realizowane sa przez organy gminy przejmującej jako jej zadania zlecone, prowadzi do konstatacji, że rada gminy przejmujacej zadania jest zatem umocowana do upoważnienia w trybie art. 39 ust. 4 usg podmiotów tam wskazanych także do wykonywania kompetencji wójta (burmistrza, prezydenta) mających zapewnić realizację zadań przekazanych, wymagających załatwiania spraw indywidualnych. Sprawą wymagająca dalszej refleksji, wykraczającej jednak już poza ramy niniejszego opracowania, jest kwestia dopuszczalności przekazywania w drodze porozumienia niektórych tylko kompetencji służących realizacji określonych zadań. W takich przy-

${ }^{35}$ Ustawa z 29 sierpnia 1997 r. - Ordynacja podatkowa, t.jedn.: Dz. U. 2012, poz. 749 ze zm. 
padkach, z pewnym uproszczeniem, przyjąć można, że rada gminy jest umocowana do przekazania w trybie art. 39 ust. 4 usg wyłącznie tych kompetencji do załatwiania spraw indywidualnych, które wyraźnie objęto porozumieniem.

W przypadku porozumień zawieranych z administracją rządowa, np. z wojewoda, rozważyć należałoby, czy podmiot przekazujący określone zadania bądź możliwość ich załatwiania tylko w określonych, przysługujących mu (wojewodzie) formach działania mógłby skutecznie wykluczyć dopuszczalność skorzystania przez radę gminy z kompetencji określonej art. 39 ust. 4 usg w zakresie spraw przekazanych porozumieniem. Zważywszy, że porozumienie zawierane jest jednak z gmina jako jednostką samorządu terytorialnego (co prawda reprezentowana przez wójta, to jednak w rezultacie zawarcia porozumienia), zadania powierzone zostaja gminie. Wojewoda zapewnić musi w porozumieniu możliwość skutecznej kontroli sposobu wykonywania powierzonych zadań, jednak - jak się zdaje - nie może ograniczyć, czy wręcz wyłączyć, możliwości stosowania regulacji ustawowych dotyczących form realizacji powierzonych zadań, w tym możliwości upoważnienia przez organ uchwałodawczy gminy podmiotów wskazanych w art. 39 ust. 4 usg do wykonywania kompetencji zasadniczo realizowanych przez organ wykonawczy. Przyjąć zatem należy, że stosowanie art. 39 ust. 4 usg w odniesieniu do zadań powierzonych gminie przez wojewodę, a wymagajacych załatwiania spraw indywidualnych jest dopuszczalne, a nadto kompetencji rady gminy w tym zakresie nie można ograniczyć na podstawie zawartego porozumienia czy też dodatkowych oświadczeń woli stron porozumienia.

W świetle powyższych ustaleń należy wreszcie udzielić odpowiedzi na pytanie o zasadność obejmowania uchwałą podejmowaną w trybie art. 39 ust. 4 usg kompetencji do dokonywania czynności instrumentalnych w stosunku do wyraźnie objętych uchwałą. Odpowiedź na tak postawione pytanie tylko pozornie wydaje się oczywista. Z pewną dozą ostrożności stwierdzić jednak można, że działanie ściśle powiązane z załatwianiem spraw indywidualnych, instrumentalne w stosunku do nich, a więc np. wszelkie działania organu prowadzącego sprawę w trybie Kodeksu postępowania administracyjnego, niezbędne do zgodnego z prawem przeprowadzenia postępowania, nie wymagają odrębnego wyraźnego umocowania uchwała. Przekazanie kompetencji do wydawania decyzji jest wszak nierozerwalnie połączone z możliwościa, a niekiedy wręcz obowiązkiem podejmowania działań przypisanych organowi prowadzącemu postępowanie i załatwiajacemu sprawę przez wydanie kończącego je rozstrzygnięcia. W innych przypadkach sprawa nie musi być już jednak tak oczywista. W wielu sytuacjach sprawą nie do końca przesądzoną może okazać się relacja pomiędzy załatwiająca sprawę indywidualną czynnością przekazaną a innymi działaniami, które np. co prawda muszą poprzedzać dokonanie czynności przekazanej, jednakże dokonywane mogą być w oderwaniu od czynności, do której udzielono upoważnienia, w tym także z powodzeniem dokonywane być moga także przez podmioty inne niż organ prowadzący postępowanie. Bliższa analiza tych zagadnień wymagałaby przeprowadzenia studiów wybranych przypadków i na tej dopiero podstawie formułowania wniosków bardziej ogólnych, co wykraczałoby już poza szczupłe ramy niniejszego opracowania. 
Ostatnią wreszcie sprawą jest zasadność wyraźnego umocowania określonych podmiotów uchwała rady podejmowana w trybie art. 39 ust. 4 usg do podejmowania działań, co do których istnieje ustawowy obowiązek ich realizowania przez określone podmioty z tej racji, że posiadają określony status. $\mathrm{Na}$ to pytanie należy udzielić odpowiedzi zdecydowanie negatywnej. Organy administracji publicznej, także organy w ujęciu funkcjonalnym, z mocy prawa powszechnie obowiąującego mają wszak obowiązek przedsiębrania działań np. z zakresu udzielania informacji publicznej bądź odmowy jej udzielenia, obowiązek wydawania zaświadczeń w zakresie określonym kpa, obowiązek załatwiania skarg oraz wniosków w trybie Działu VIII kpa i wielu innych. Sa to ustawowe obowiązki tych podmiotów obowiązujące je $\mathrm{z}$ racji wykonywania określonych zadań, a więc rada gminy nie tylko nie musi, ale wręcz nie może skutecznie wyposażać tych podmiotów w kompetencje, które przysługują im z mocy prawa.

\section{WAŻNIEJSZE KONKLUZJE}

Niezależnie od przedstawionych w tekście opracowania wniosków bardziej szczegółowych, wskazać należy, że z treści art. 39 ust. 4 usg wynika dopuszczalność powierzania przez radę gminy kompetencji organu wykonawczego gminy do załatwiania wszelkich spraw indywidualnych mieszczących się w zakresie zadań gminy, zarówno ustawowych, jak i nabytych przez gminę droga zawartych porozumień. Zakresu pojęcia „sprawa indywidualna” nie można żadną miarą utożsamiać z pojęciem ,wymagajacca rozstrzygnięcia sprawa indywidualna”, o czym mowa w kpa. Powierzenie kompetencji do załatwiania określonych spraw indywidualnych obejmuje ze swej istoty umocowanie do podejmowania działań instrumentalnych w stosunku do wyraźnie powierzonych oraz funkcjonalnie z nimi powiązanych. Nadto powierzenie do realizacji określonych zadań skutkuje tym, że podmiot, któremu powierzono określone zadania, staje się podmiotem administracji publicznej z mocy prawa zobowiązanym do podejmowania różnych działań, np. w zakresie załatwiania skarg i wniosków, wydawania zaświadczeń, udostępniania informacji z zakresu informacji publicznych i wielu innych.

Powyższe uwagi oraz płynące z nich wnioski zostały sformułowane z pełną świadomościa autora o konieczności kontynuowania analiz we wskazanych kierunkach, zwłaszcza że jak do tej pory nie doczekały się one obszerniejszych analiz, które mogłyby doprowadzić do ujednolicenia stanowiska zarówno doktryny, jak i orzecznictwa nie tylko sądowoadministracyjnego, lecz także organów sprawujących nadzór nad jst.

dr hab. Krystian Ziemski

Profesor Uniwersytetu im. Adama Mickiewicza w Poznaniu

krystian.ziemski@ziemski.com.pl 


\section{ABILITY TO DELEGATE COMPETENCES BY A COMMUNE AND MUNICIPALITY COUNCIL}

\section{Sum mary}

The paper is concerned with the scope of the concept an 'individual public administration matter requiring attention,' which is disputable both in literature and in case law. Determinations made in this respect affect the applicability of Article 39.4 of Communal Self-Government Act concerning the commune council's ability to delegate its competences of an executive body to executive bodies of the commune's auxiliary units and other parties.

According to certain doctrines, an individual public administration matter must be equated with the scope of the concept of 'administrative decision' within the meaning assigned to it through the Act - the Code of Administrative Procedure. The article shows that this view is a consequence of identifying the concept of 'resolving' with handling individual public matters. However, not every individual public matter requires a resolution as to the legal consequences of the given facts. A major part of individual matters are handled through actual activities that do not require any issuance of an administrative decision. The article further includes discussion of whether delegation of competence to attend to certain matters should at the same time require express authorisation to take actions which are instrumental to the expressly delegated competences, actions which are functionally linked to these competences, and the rationale behind express delegation, as well as taking actions being the obligation of entities implementing public tasks (e.g. issuing certificates/statements of fact, or undertaking actions governed by Disclosure of Public Information Act). 
